\title{
Exploring the Effects of Land-Cover Configuration, Body Size and Trophic Diversity on the Avifauna Richness of Prince Edward Island, Canada
}

\author{
Marina Silva-Opps ${ }^{1 *}$, Joshua Mailhiot ${ }^{2}$, Sheldon B. Opps ${ }^{1}$, Javier Sanchez ${ }^{3}$ \\ ${ }^{1}$ University of Prince Edward Island, Charlottetown, Canada \\ ${ }^{2}$ Canadian Wildlife Service, Environmental Stewardship Branch, Environment Canada, Mount Pearl, Canada \\ ${ }^{3}$ Atlantic Veterinary College, University of Prince Edward Island, Charlottetown, Canada \\ Email: *msilva@upei.ca
}

How to cite this paper: Silva-Opps, M., Mailhiot, J., Opps, S.B. and Sanchez, J. (2019) Exploring the Effects of Land-Cover Configuration, Body Size and Trophic Diversity on the Avifauna Richness of Prince Edward Island, Canada. Open Journal of Ecology, 9, 216-237.

https://doi.org/10.4236/oje.2019.97018

Received: June 14, 2019

Accepted: July 27, 2019

Published: July 30, 2019

Copyright $\odot 2019$ by author(s) and Scientific Research Publishing Inc. This work is licensed under the Creative Commons Attribution International License (CC BY 4.0).

http://creativecommons.org/licenses/by/4.0/

\section{(c) (i) Open Access}

\begin{abstract}
We explored the effects of land-cover configuration, body size and trophic diversity in determining avian species richness on Prince Edward Island, Canada. Data on avian species richness were obtained from the Maritime Breeding Bird Atlas data. Prince Edward Island was divided into 97 sampling cells of $10 \times 10 \mathrm{~km}$. Land-cover metrics were calculated using a forest inventory database, Fragstats and ArcView version 8.1. The relationships between avian species richness and explanatory variables were explored using correlation analysis, mixed forward-backward stepwise analysis, generalized linear models and Akaike's information criterion. Models predicted between 27\% and $63 \%$ of the variability in species richness, attributing substantial explanatory power to both the average body size and the range of body size spanned by the avian community. The body-size frequency distribution showed that avian communities were dominated by species weighing between 50 and $80 \mathrm{~g}$. Habitat metrics associated with forests were more important to the avifauna than those related to agriculture. Avian species richness also decreased with both the fragmentation and isolation of wetlands. The total area covered by the human infrastructure land-cover and its subdivision were also important. Clearly, body size plays a key role in determining the diversity of birds on Prince Edward Island. In particular, species weighing 50 - $80 \mathrm{~g}$ appear to have sufficient resources to be successful on Prince Edward Island's landscapes. Our findings also highlighted the importance of controlling the expansion of human infrastructure and both the fragmentation and reduction in size of wetlands to maintain avian species richness patterns.
\end{abstract}




\section{Keywords}

Species Richness, Body Size, Birds, Spatial Variation, Land-Cover Structure, Habitat Fragmentation

\section{Introduction}

Understanding the factors that determine spatial variations in species richness has long been a fundamental question in ecology [1] [2] [3] [4]. Although the precise mechanisms for the creation and maintenance of patterns of species richness are still hotly debated [5] [6] it is usually recognized that species richness patterns can be influenced by a variety of environmental, historical and life history factors that can operate at different temporal and spatial scales.

In large spatial scale, studies have shown that factors such as latitude, climate, elevation, primary productivity and habitat heterogeneity can affect species richness patterns [7] [8]. Because many of these factors also explain abundance and body-size patterns at large spatial scales (e.g. [9] [10]), studies examining species richness patterns often explore simultaneously the relationships between species richness and body size. Studies conducted at large spatial scales have found that species richness is at its highest at intermediate body sizes, suggesting a numerical dominance of species of this size [11] [12]. Furthermore, studies conducted at large spatial scales have typically examined the relationship between species richness and body size by focusing on the species-body size distribution (i.e. species body sizes spanned by the whole assemblage or community) and the factors that shape this distribution [13] [14]. The few studies that have examined the species richness-body-size interspecific relationship at large spatial scales have found a negative association between these two variables [15] [16], suggesting that species-rich communities are generally composed of small-sized species. Studies conducted at smaller spatial scales have generally failed to show a clear trend between species richness and body size (e.g. [9]).

Factors associated with human land-use development and habitat fragmentation have been shown to be particularly important in determining species richness patterns at small spatial scales [17] [18]. Global patterns of land use have resulted in widespread conversion of natural environments to landscapes dominated by agricultural fields, roads, and other human infrastructures. For example, wetlands have declined by more than $50 \%$ in North America during the last century mainly due to their conversion into agricultural land [19]. The resulting shift from continuous habitat to disjoined patches of habitat has also drastically changed the landscape context in which the remaining natural habitats are embedded [20] [21]. Habitat fragmentation can alter the span of body sizes covered by an animal community as highly fragmented habitats may only be able to support small-bodied species due to a decrease in resource availability (e.g. [22]). If this is true, we predict that as human-induced disturbances (i.e. habitat frag- 
mentation, land-use activities, etc.) increase, there should be a decrease in the average body size of the community and/or in the span of body sizes covered by the community.

In this study, we investigate the regional patterns of species richness of the breeding avifauna of Prince Edward Island (PEI), Canada. Specifically, the objectives of this study are threefold. First, to evaluate the relative importance of body size, trophic diversity, land-cover types and human disturbances in determining avian species richness patterns at the regional scale. Specifically, we predict a dominance of intermediate- or small-sized species as habitats become more fragmented which will also affect both composition and trophic diversity of animal communities [23]. Our second objective is to assess the relative contribution of the structure, configuration and diversity of land-cover types to the variation in avian species richness values. In particular, we are interested in identifying which landscape configurations and structures could enhance avian species richness at the regional spatial scale. Our final objective is to examine the relationship between species richness and explanatory variables (body size, trophic diversity and land-cover types) for different avian groups (i.e. landbirds, shorebirds, waterfowl and seabirds). We hypothesize that both body size and trophic diversity will be important determinants of species richness for all avian groups. We expect that the structure and configuration of wetlands will be a significant predictor of waterfowl species richness, and that species richness of both landbirds and shorebirds will be influenced by agriculture and forest areas. Finally, we expect that the structure and configuration of land-cover types will not influence the species richness of seabirds.

\section{Methods}

\subsection{Data}

PEI is located in the St. Lawrence Basin of Eastern Canada $\left(46.5107^{\circ} \mathrm{N}, 63.4168^{\circ} \mathrm{W}\right)$. The island is relatively flat (146 m above sea level) and covers an area of $\sim 5665.6$ $\mathrm{km}^{2}$. PEI has a mild maritime climate, strongly influenced by the warm waters of the Gulf of St. Lawrence. Each year, the island receives about $890 \mathrm{~mm}$ of rain and approximately $290 \mathrm{~cm}$ of snow. Since the European colonization in the $17^{\text {th }}$ century, anthropogenic activities such as agriculture and forestry have led to drastic reduction and fragmentation of much of the natural habitat of the island. Less than 1\% of the original Acadian Forest still remains on PEI [24]. During the last century, large-scale crop production has also led to the expansion of cultivated areas and has increased pressure on forest habitats [25]. This development has also resulted in a reduction or transformation of wetlands and an increase in human population density and infrastructure.

Data on avian species occurrence were obtained from the Maritime Breeding Bird Atlas [26]. PEI was divided into 97 sampling cells (each $10 \times 10 \mathrm{~km}$ ) out of which a different set of sampling cells was randomly selected for yearly breeding surveys between 1986 and 1990. Each year, trained observers used auditory and 
visual cues to detect the presence of avian species in all habitat types (e.g. agricultural fields, forests, hedgerows, along roads, human-use areas, wetlands, seashores, etc.) within a sampling cell. Surveys began 15 - 20 minutes before sunrise and ended within 4 hours after sunrise. The last year (i.e. 1990) was devoted to ensuring that each sampling cell was surveyed at least once and to limit the observer bias that could arise from a priori knowledge of the avifauna of certain sampling cells or from differential census intensity. First, we assessed the quality of the Breeding Bird Atlas data by comparing species richness values with the total number of species generally known to occur in PEI based on historical data, previous surveys and provincial records [27]. Second, we included in the analyses a variable indicating the total sampling effort per cell (total number of hours spent by all observers in a sampling cell) to account for differences in sampling effort. The information on total sampling effort per cell was also used to exclude 21 sampling cells from the analyses as they were insufficiently sampled. Therefore, the analyses presented in this study are based on 76 sampling cells (Figure 1). Species richness per sampling cell was calculated as the total number of species observed during the 5-years survey period. An effort was made to exclude from the analyses any avian species known to be a vagrant on PEI. Avian taxonomic classification followed Sibley and Monroe [28]. In this study, we have not included any phylogenetic corrective procedure [29] [30] in our analyses for various reasons. Unfortunately, a detailed phylogenetic description for the birds occurring on PEI is currently unavailable. Phylogenetic relationships provide

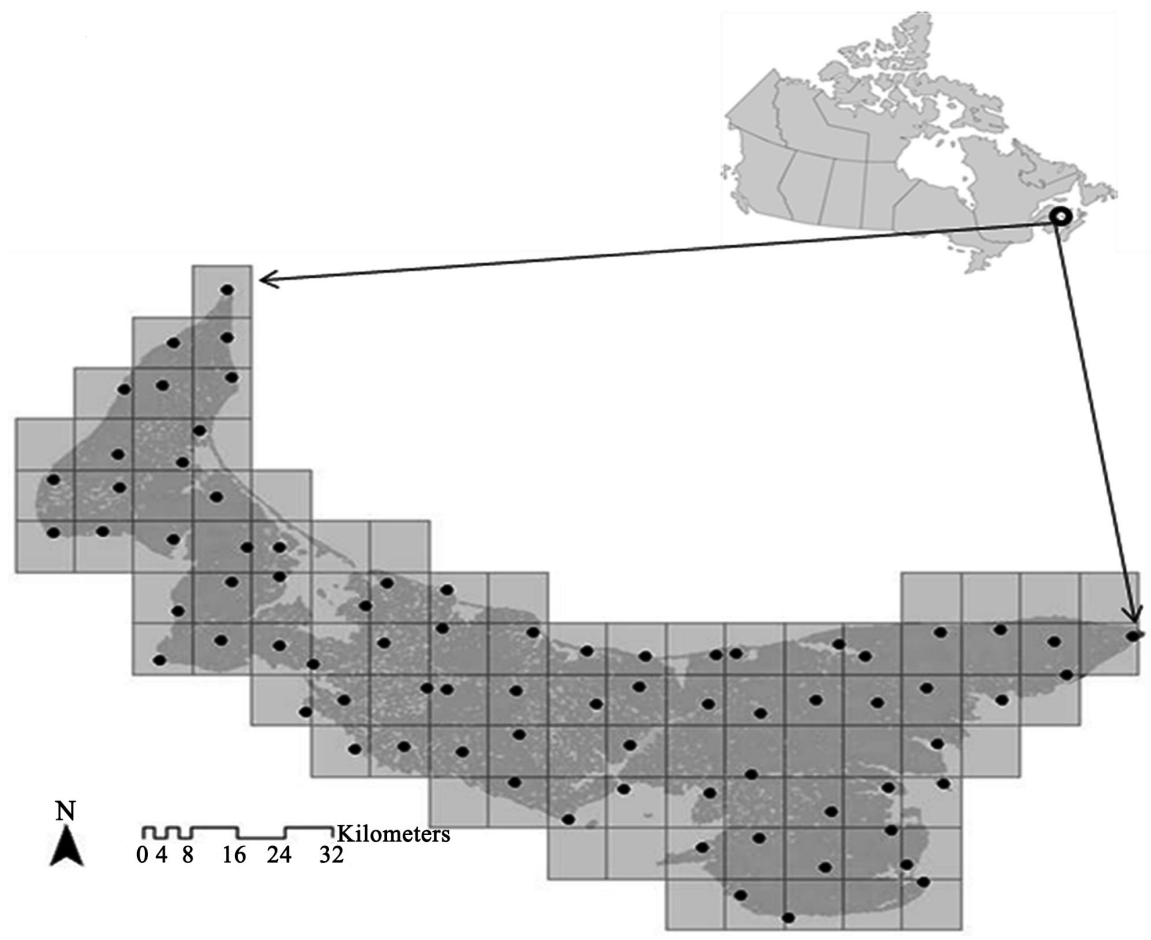

Figure 1. Map of Prince Edward Island in relation to Canada $\left(46^{\circ} \mathrm{N}, 63^{\circ} \mathrm{W}\right)$ showing the 97 sampling cells (each $10 \mathrm{~km} \times 10 \mathrm{~km}$ ) used in this study. Solid dots indicate the sampling location for each cell. The scale-bar refers to Prince Edward Island only. 
information on what happened millions of years ago while population abundance is controlled by events that happen on a much shorter time scale [29]. Thus, it has been argued that phylogenetic methods favour explanations based on phylogeny at the expense of explanations based on ecology [31] [32] [33]. Since we were interested in assessing the relative importance of the land-cover on the structure of avifauna communities occurring on PEI, we did not include any phylogenetic corrective procedure in our analyses.

Body size was measured as the average adult body mass ( $\mathrm{M} ; \mathrm{g}$ ) for each avian species and was obtained from Dunning [34]. Following Blackburn and Hawkins [35], we also used a "community" approach that consisted of calculating an average $M$ (Average_M) for all species occurring within each sampling cell. This approach was also used to calculate a value for the range of $M$ (Range_M) spanned by all the species occurring within each sampling cell. We also calculated an index of trophic diversity for each avian community. First, each avian species was broadly classified into a trophic group (carnivore, herbivore, omnivore, insectivore). Then, we calculated an index of trophic diversity (Troph_D) based on the Shannon-Weiner diversity index $\left(\mathrm{T}^{\prime}=\sum t_{i} \ln t_{j}\right.$ where $t_{i}$ is the proportion of species of a given trophic category; [36]). Avian species were also classified into landbird, seabird, shorebird or waterfowl using basic habitat preference information [26].

Land-cover types (forests, wetlands, agriculture, roads and other human infrastructures) encompassed within sampling cells were obtained using the 1990 PEI forest inventory data and ArcView version 8.1. The data from 1990 forest inventory were used to be consistent with the avian data that were collected between 1986 and 1990. Fragstats version 3.3 [37] was used to calculate a set of metrics that described the structure, configuration and diversity of each land-cover type. Habitat metrics that characterize the configuration and structure of fragmented landscapes (e.g. size, shape, proximity of habitat patches to other areas of suitable habitat) have been shown to affect species richness patterns and the composition of animal communities [38] [39] [40]. Therefore, we selected 14 metrics that quantified different aspects of the structure, configuration and diversity of land-cover types (Table 1).

Table 1. Brief definitions of the selected FRAGSTATS land-use metrics used in this study. Full definitions and associated equations for these metrics can be found in McGarigal \& Marks [37].

\begin{tabular}{llll}
\hline Acronym & Metric Name & Units & Description \\
$\begin{array}{l}\text { Total Land } \\
\text { Area }\end{array}$ & Patch area & ha & Total land/wetland-area minus sea-occupied area. \\
Np & $\begin{array}{l}\text { Number of } \\
\text { patches }\end{array}$ & None & $\begin{array}{l}\text { The number of patches of the corresponding land-cover } \\
\text { within a sampling cell; reflecting landscape pattern. }\end{array}$ \\
Pd & Patch density & $\# / 100$ ha & $\begin{array}{l}\text { Number of patches per unit area of a specific land-cover } \\
\text { type; it increases with landscape heterogeneity. }\end{array}$
\end{tabular}




\section{Continued}

\begin{tabular}{|c|c|c|c|}
\hline Pland & $\begin{array}{l}\text { Percentage of } \\
\text { landscape }\end{array}$ & Percent & $\begin{array}{l}\text { Percentage of area occupied by a given land-cover type } \\
\text { within a sampling cell. }\end{array}$ \\
\hline Shape & Shape index & None & $\begin{array}{l}\text { Measures the total edge or edge density while adjusting } \\
\text { for the size of an area for a given land-cover type. "Shape" } \\
\text { increases as the patch edges become more irregular and as } \\
\text { the length of patch edges increases. }\end{array}$ \\
\hline Para & $\begin{array}{l}\text { Perimeter-area } \\
\text { ratio }\end{array}$ & None & $\begin{array}{l}\text { Ratio of the patch perimeter to area. It measures shape } \\
\text { complexity but without standardization to a simple } \\
\text { Euclidean shape (e.g. square). }\end{array}$ \\
\hline Frac & $\begin{array}{l}\text { Fractal } \\
\text { Dimension } \\
\text { index }\end{array}$ & None & $\begin{array}{l}\text { Shape complexity across a range of spatial scales } \\
\text { (patch sizes). It approaches } 1 \text { for shapes with very simple } \\
\text { perimeters (e.g. square) and approaches } 2 \text { for shapes with } \\
\text { highly convoluted, plane-filling perimeters. }\end{array}$ \\
\hline Clumpy & $\begin{array}{l}\text { Clumpiness } \\
\text { index }\end{array}$ & None & $\begin{array}{l}\text { Frequency with which different pairs of patch types } \\
\text { appear side-by-side within a sampling cell. "Clumpy" } \\
\text { equals } 0 \text { when the focal patch type is distributed } \\
\text { randomly, and approaches } 1 \text { when the patch type is } \\
\text { maximally aggregated. }\end{array}$ \\
\hline Contag & $\begin{array}{l}\text { Contagion } \\
\text { index }\end{array}$ & Percent & $\begin{array}{l}\text { Inversely related to edge density. When edge density is } \\
\text { very low (e.g. when a single class occupies a very large } \\
\text { percentage of the landscape), "Contag" is high, and vice } \\
\text { versa. "Contag" is affected by both the dispersion and } \\
\text { interspersion of patch types. }\end{array}$ \\
\hline Pladj & $\begin{array}{l}\text { Percentage } \\
\text { of like } \\
\text { adjacencies }\end{array}$ & Percent & $\begin{array}{l}\text { Measures the degree of aggregation of patch types. Thus, } \\
\text { a landscape containing larger patches with simple shapes } \\
\text { will contain a higher percentage of like adjacencies than a } \\
\text { landscape with smaller patches and more complex shapes. } \\
\text { Contrary to "Contag", "Pladj" measures only dispersion } \\
\text { and not interspersion. }\end{array}$ \\
\hline $\mathrm{Ai}$ & $\begin{array}{l}\text { Aggregation } \\
\text { index }\end{array}$ & Percent & $\begin{array}{l}\text { Takes into account only the like adjacencies involving } \\
\text { the focal class, not adjacencies with other patch types. } \\
\text { AI increases as the focal patch type is increasingly } \\
\text { aggregated and equals } 100 \text { when the patch type is } \\
\text { maximally aggregated into a single, compact patch. }\end{array}$ \\
\hline $\mathrm{Iji}$ & $\begin{array}{l}\text { Interspersion } \\
\text { \& juxtaposition } \\
\text { index }\end{array}$ & Percent & $\begin{array}{l}\text { This metric is based on adjacent patches and isolates } \\
\text { interspersion or intermixing of patch types. "Iji" } \\
\text { approaches } 0 \text { when the corresponding patch type is } \\
\text { adjacent to only } 1 \text { other patch type and the number of } \\
\text { patch types increases. "Iji" = } 100 \text { when the corresponding } \\
\text { patch type is equally adjacent to all other patch types. }\end{array}$ \\
\hline Acronym & Metric Name & Units & Description \\
\hline Sidi & $\begin{array}{l}\text { Simpson's } \\
\text { diversity index }\end{array}$ & None & $\begin{array}{l}\text { Measures diversity (heterogeneity) of the landscape. } \\
\text { "Sidi" approaches } 1 \text { as the number of different patch types } \\
\text { increases and the proportional distribution of area among } \\
\text { patch types becomes more equitable. }\end{array}$ \\
\hline Shdi & $\begin{array}{l}\text { Shannon's } \\
\text { diversity index }\end{array}$ & None & $\begin{array}{l}\text { Measures diversity (heterogeneity) of the landscape. } \\
\text { "Shdi" increases as the number of different patch types } \\
\text { increases and the proportional distribution of area among } \\
\text { patch types becomes more equitable. "Shdi" is more } \\
\text { sensitive to rare patch types than "Sidi". }\end{array}$ \\
\hline
\end{tabular}




\subsection{Data Analysis}

All statistical analyses were carried out using R version 2.7.0

(http://www.r-project.org). All variables were tested for normality using the Kolmogorov-Smirnov test and were transformed logarithmically if needed. The relationships between avian species richness and explanatory variables were examined using correlation analysis, mixed forward-backward stepwise analysis and generalized linear models. First, we tested all the explanatory variables for multicollinearity by examining cross-correlations among them using Pearson correlation analysis. Only variables with cross-correlation $<0.6$ were retained for further analyses. Second, we examined the relationships between species richness and the selected explanatory variables for all birds pooled together and also each avian group separately (i.e. landbirds, shorebirds and waterfowl) using a mixed forward-backward stepwise analysis. The use of this analysis allowed us to further reduce the number of explanatory variables by eliminating insignificant predictors for the analyses of all species and separated avian groups, except for seabirds. The dataset for seabirds included too many zeroes to allow us for a separate statistical analysis.

Third, we undertook a spatial analysis to evaluate the presence of an autocorrelation structure in the species richness data. The presence of autocorrelation will violate the independence assumption in many regression analyses [41]. As the distribution patterns of birds are affected by environmental, biological and anthropogenic factors, the spatial structure present in those factors may also have spill-over effects on species richness patterns [42]. Using the latitude and longitude values of each sampling cell, we determined for each sampling cell the locations of the four nearest neighbours cells. Then, using the species richness values of the four nearest neighbours, we calculated a value that represented the average species richness of the four nearest sampling cells (here after called the average nearest neighbor-species richness; near-richness). We then examined the spatial autocorrelation structure in the near-richness values using correlograms [41]. Correlograms were constructed by plotting Moran's I values on the $\mathrm{y}$-axis against distance classes of sampling cells on the $\mathrm{x}$-axis. For this study, we generated correlograms of the near-richness data at 10 geographic distance classes. If these correlograms indicated that there was spatial autocorrelation in any distance class, then the variable near-richness was used as a potential explanatory variable in the modeling component of this study. Otherwise, this variable was excluded from further analyses.

Finally, models were developed to predict the richness of all bird species together and for each avian group separately using all selected explanatory variables. Several generalized linear regression models, including Poisson distribution, negative binomial distribution, and quasi-Poisson distribution can be used to model species richness data, but there is no real consensus regarding which of these regression procedures is the most appropriate [43] [44]. Thus, we first developed predictive models using each of these three regression procedures and 
then selected the "best model" for each avian group using the Akaike's information criterion (AIC) value. For each selected model, we also provide the coefficient of determination or $R^{2}$ value. No genuine $R^{2}$ values are available in generalized linear models (GLMs), but they can be approximated by dividing the residual deviance statistic (a measure of goodness of fit of the model) by the percentage deviation explained by the model [45]. Spatial autocorrelation in the residuals of these models was examined using Moran's I and correlograms. The presence of spatial autocorrelation in the residuals indicated that the GLM model did not adequately describe species richness patterns, and some important but spatially patterned variables were missed from the model.

\section{Results}

A total of 156 different breeding bird species were observed in this study. Species richness varied between 7 and 89 species among sampling cells. The combination of correlation and mixed forward-backward stepwise analyses reduced the number of meaningful explanatory variables by $~ 75 \%-85 \%$ depending upon the avian group, with only a few variables that were common to all groups (Table 2). Out of the three different regression procedures examined with GLM analysis, Poisson regression produced the best predictive models whether all bird species were pooled together or separated into groups (Table A1). Therefore, only the predictive models using Poisson regression will be discussed in the following sections.

Table 2. Explanatory variables selected for each avian group using cross-correlation analysis (Pearson correlation analysis) and stepwise forward multiple regression analysis. Only variables with cross-correlation $<0.6$ are shown here. "Life History" variables are: "Average_M" (average body size of all the species), "Range_M" (range of body size spanned by all the species) and "Troph_D" (index of trophic diversity) of all species occurring within each sampling cell. "Habitat" variables are landscape metrics that characterize the forest, wetland, and agriculture land-cover types. "Human Disturbance" includes landscape metrics that characterize human infrastructures (Infrastr) and roads. "Other Variables" includes "Effort" (total sampling effort per cell) and "Near_Richness" (average species richness of the four nearest sampling cells). Table 1 provides brief definitions of the acronyms used for habitat and human disturbance variables.

\begin{tabular}{|c|c|c|c|}
\hline All Birds & Landbirds & Shorebirds & Waterfowl \\
\hline \multicolumn{4}{|c|}{ Life-History Trait } \\
\hline Average_M & Average_M & Range_M & Average_M \\
\hline \multirow[t]{2}{*}{ Range_M } & Range_M & & Range_M \\
\hline & Troph_D & & Troph_D \\
\hline \multicolumn{4}{|c|}{ Habitat } \\
\hline Forest_Np & Agriculture_Area & Agriculture_Shape & Forest_Np \\
\hline Forest_Shape & Forest_Area & Forest_Shape & Forest_Shape \\
\hline Wetland Area & Forest Np & Wetland Area & Wetland Area \\
\hline
\end{tabular}




\section{Continued}

\begin{tabular}{|c|c|c|c|}
\hline Wetland_Pladj & Forest_Shape & Wetland_Iji & Wetland_Np \\
\hline \multirow[t]{5}{*}{ Wetland_Iji } & Wetland_Area & & \\
\hline & Wetland_Np & & \\
\hline & Wetland_Pladj & & \\
\hline & Wetland_Iji & & \\
\hline & \multicolumn{2}{|c|}{ Human Disturbance } & \\
\hline Infrastr_Area & Infrastr_Area & Infrastr_Area & Infrastr_Area \\
\hline Infrastr_Np & Infrastr_Np & Infrastr_Np & Infrastr_Np \\
\hline Infrastr_Para & Infrastr_Para & Infrastr_Pladj & Infrastr_Para \\
\hline Infrastr_Pladj & Infrastr_Pladj & Road_Clumpy & Infrastr_Pladj \\
\hline Road_Area & & & Road_Pd \\
\hline \multicolumn{4}{|l|}{ Road_Para } \\
\hline \multicolumn{4}{|c|}{ OtherVariables } \\
\hline Effort & Effort & Effort & Effort \\
\hline Near_Richness & Near_Richness & Near_Richness & Near_Richness \\
\hline
\end{tabular}

The pattern of spatial autocorrelation in the species richness values when all species were grouped together was characteristic of a cline, with significant positive autocorrelation at small distance scales and significant negative correlation at the largest distance scales (Figures 2(a)-(d)). When examining each avian group separately, the spatial autocorrelation in species richness was less obvious though some significant positive correlations at small distances were still present. However, Poisson regression significantly reduced spatial autocorrelation in richness values whether all bird species were examined together or separated into groups (Figures $2(\mathrm{e})-(\mathrm{h})$ ). Poisson regression produced models that predicted between $27 \%$ to $63 \%$ of the variability in avian species richness. Only the variables Range_M, Forest_Shape, Wetland_Area and Effort were common to all models. Three other variables (Average_M, Infrastr_Area and Infrastr_Np) were significant for three of the four avian groups examined in this study. The variable near-richness was only significant in the model predicting species richness of all bird species pooled together (Table 3).

\section{Influence of Body Size, Trophic Diversity and Land-Cover Types}

Poisson regression modeling attributed substantial explanatory power to both Average_M and Range_M in most predictive models (Table 3). When all avian species were pooled together, species richness decreased with Average_M (Figure 3(a)). Similar trends were obtained when avian data were separated into groups, except for waterfowl that showed the opposite trend (Table 3). Species richness increased with Range_M whether all bird species were pooled together (Figure 3(b)) or separated into groups (Table 3). A frequency distribution of all 
Table 3. Poisson regression models ( $\mathrm{p}<0.01$ for all models) relating avian richness at the species, genus and family levels on Prince Edward Island to explanatory variables. $R^{2}$ is the proportion of variability in the dataset that is accounted by the model. Variable abbreviations are listed in Table 1.

\begin{tabular}{ccc}
\hline Species Richness & Genus Richness & Family Richness \\
\hline & Life History & \\
-0.88 Average M & -0.77 Average M & -0.35 Average M \\
0.84 Range M & 0.75 Range M & 0.59 Range M \\
& Habitats & \\
$-1.47 \times 10^{-3}$ For_Np & $-1.93 \times 10^{-3}$ & \\
-0.95 For_Shape & -0.84 For_Shape & \\
$3.2 \times 10^{-4}$ Wet_Area & $3.15 \times 10^{-3}$ Wet_Iji & \\
$-2.5 \times 10^{-3}$ Wet_Np & Human Disturbance & \\
& $-3.40 \times 10^{-4}$ Infrastr_Area & \\
$-4.31 \times 10^{-4}$ Infrastr_Area & $3.51 \times 10^{-3}$ Infrastr_Np & \\
$4.47 \times 10^{-3}$ Infrastr_Np & $4.78 \times 10^{-4}$ Infrastr_Para & \\
$4.60 \times 10^{-4}$ Infrastr_Para & 0.071 Infrastr_Pladj & \\
0.065 Infrastr_Pladj & $1.05 \times 10^{-3}$ Road_Area & \\
$7.78 \times 10^{-4}$ Road_Area & Other Variables & \\
& $5.28 \times 10^{-3}$ Effort & 0.003 Effort \\
$6.4 \times 10^{-3}$ Effort & $-1.7 \times 10^{-3}$ Near-Richness & -0.23 Near-Richness \\
$-3.6 \times 10^{-3}$ Near-Richness & $R^{2}=0.28$ & $R^{2}=0.39$ \\
$R^{2}=0.27$ & &
\end{tabular}

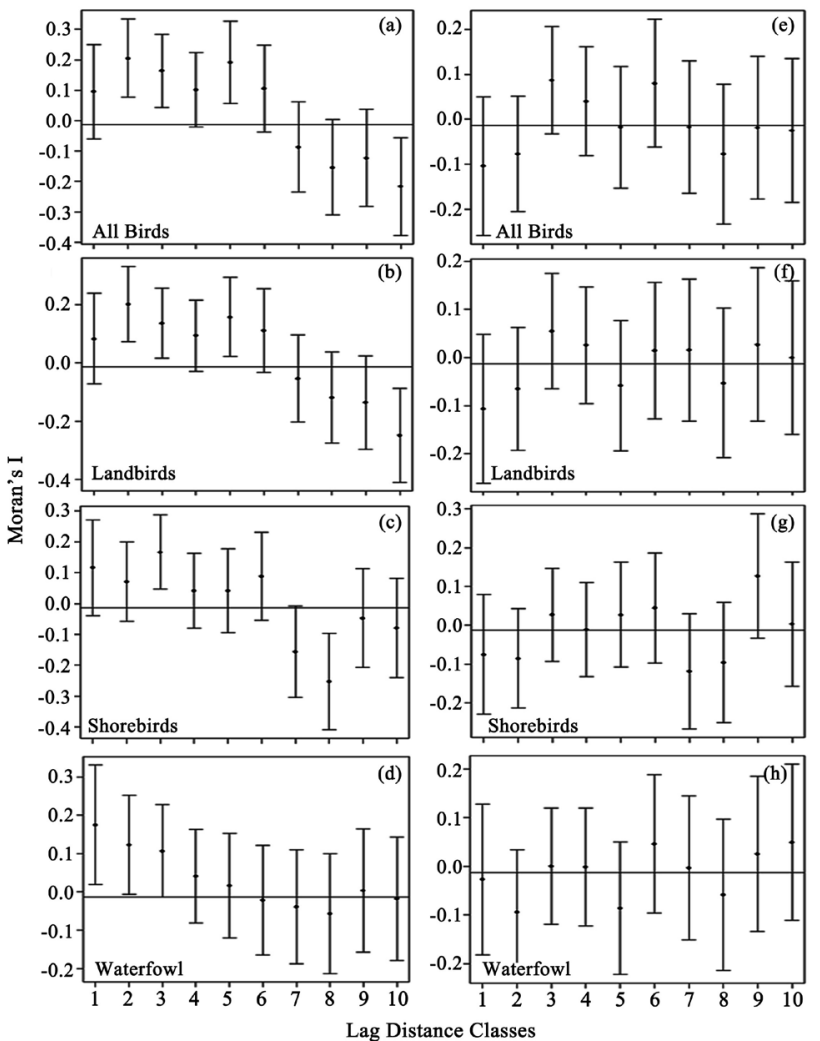

Figure 2. Spatial correlograms of Moran's I for raw species richness values (a-d) and for residuals after fitting Poisson regression models (e-h). The abscissa is lag distance classes and the ordinate Moran's I coefficients. For each plot, vertical lines represent the standard deviations of the Moran's I coefficient of each lag distance class. 


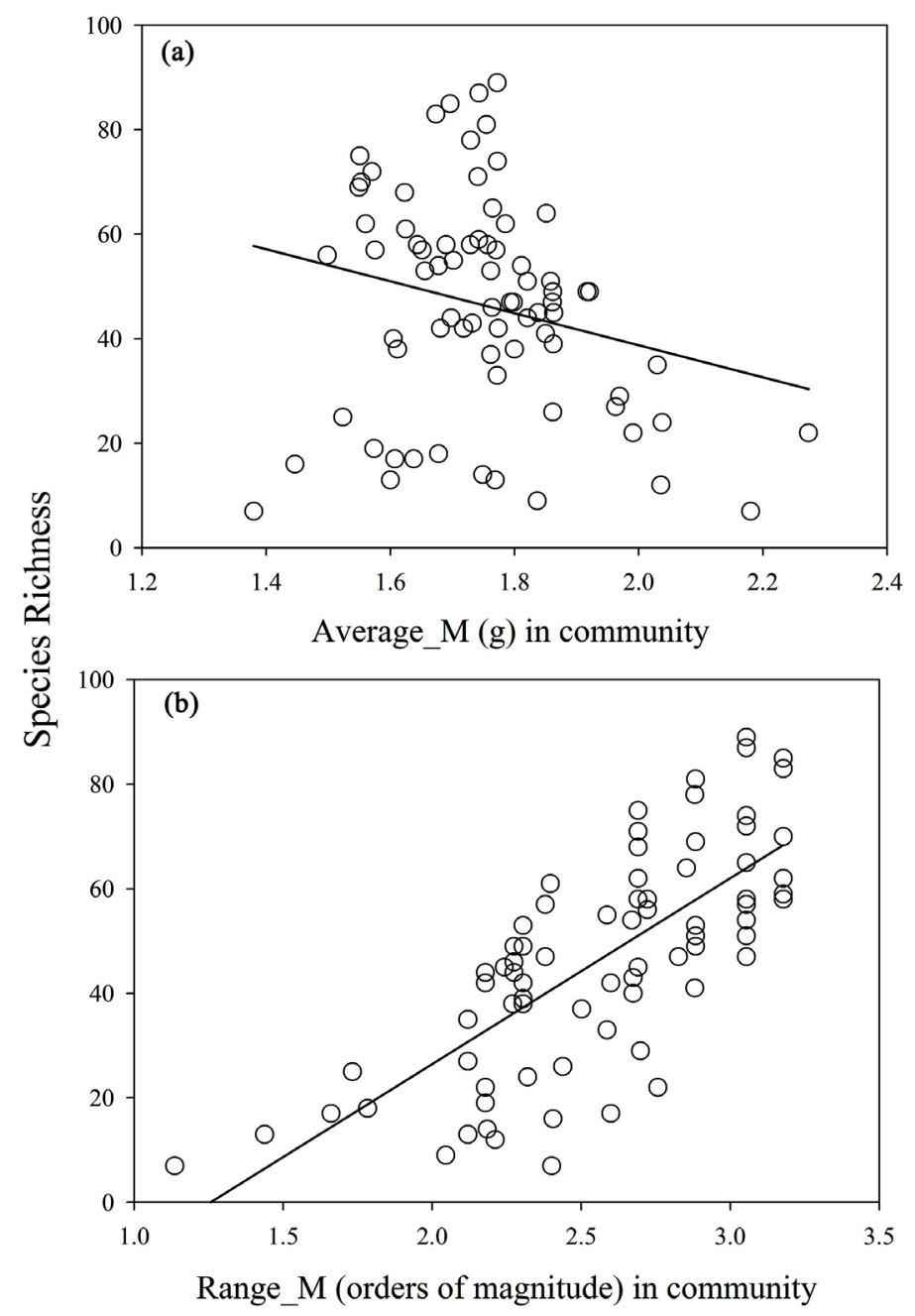

Figure 3. Relationship between species richness and both (a) the average body size and (b) the range of body size of all species composing avian communities based on Poisson regression models presented in Table 3.

Range_M values showed that $\mathrm{M}$ varied by 2.5 to 3 orders of magnitude for more than $50 \%$ of avian communities (Figure 4(a)). A frequency distribution of Average- $\mathrm{M}$ values from all avian communities indicated the dominance of species weighing about $60 \mathrm{~g}$ with the majority of species falling into the range between 50 and 80 g (Figure 4(b)). Trophic diversity was only significantly associated with the species richness of landbirds and waterfowl (Table 4).

Habitat metrics associated with forests were more important to the avifauna of PEI than those related to agricultural lands. Forest_Shape negatively affected species richness whether all species were pooled together or separated into groups. This suggested an increase in species richness as forest patches become more compact or regular in shape (i.e. square or almost square). With the exception of shorebirds, avian species richness decreased with Forest_Np, indicating that species richness is negatively affected by the fragmentation or subdivision of the forest land-cover. Species richness also increased significantly with the total 
area covered by wetlands (Wetland_Area) whether all bird species were pooled together or were separated into groups. Landbirds were negatively associated with Wetland_Pladj, suggesting that these birds were the least diverse in areas dominated by highly disaggregated wetlands (i.e. small wetlands with more complex shapes). For both landbirds and shorebirds, species richness was also influenced by the interspersion of wetlands (Wetland_Iji) with species richness being the highest in areas where wetlands were equally interspersed or adjacent to each other.

Several variables characterizing areas directly occupied by human infrastructure were also significant determinants of avian species richness in PEI. In particular, metrics that were related to the total area (Infrastr_Area), subdivision or number of occupied patches (Infrastr_Np), complexity of patch shapes (Infrastr_Para) and interspersion (Infrastr_Iji) of the human infrastructure land-cover were significantly related to avian species richness (Table 2). Roads were only minor predictors of species richness.

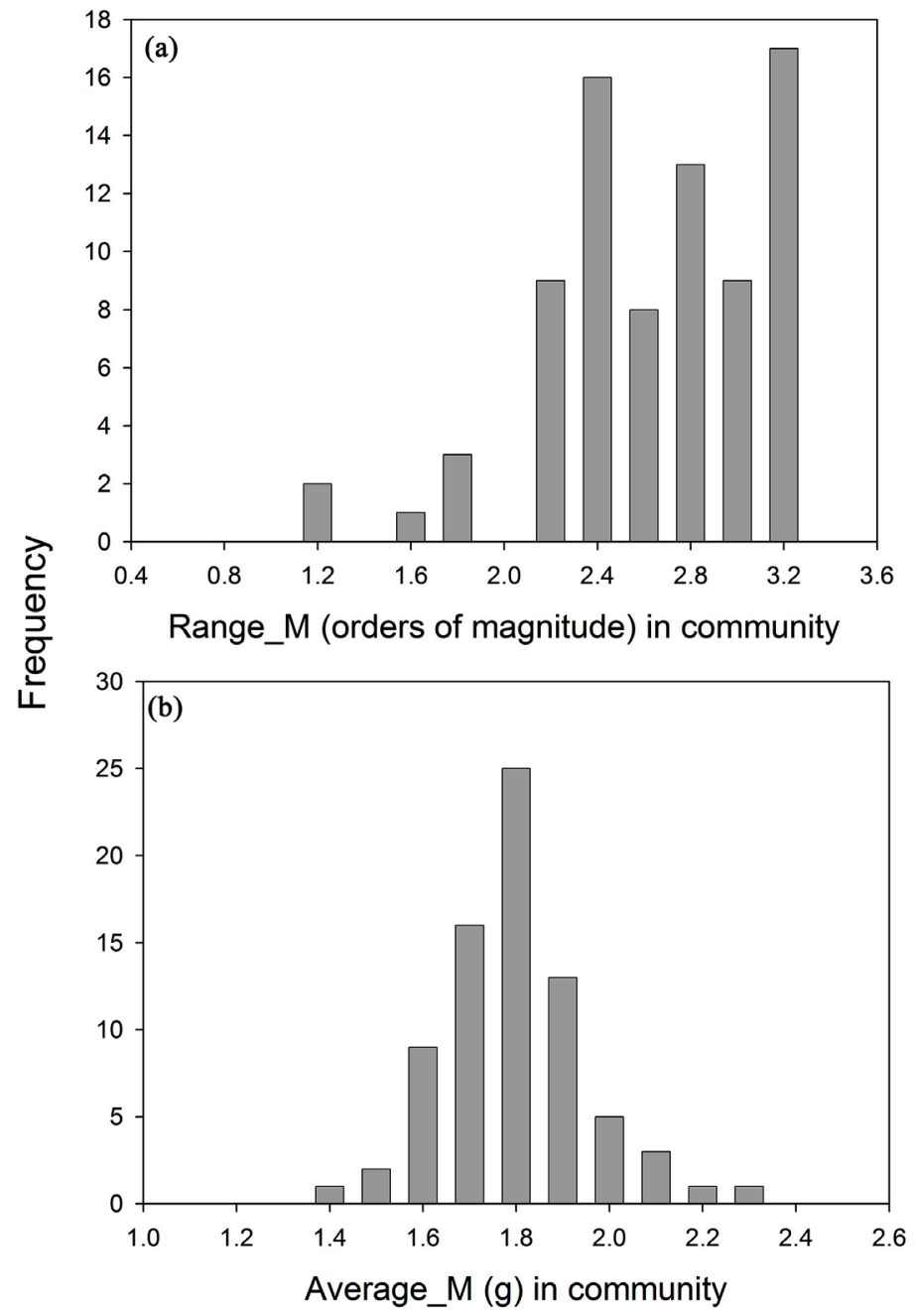

Figure 4. Frequency distribution of (a) the range of body size and (b) the average body size of all species composing avian communities. 
Table 4. Poisson regression models ( $\mathrm{p}<0.01$ for all models) relating avian species richness on Prince Edward Island to explanatory variables. $R^{2}$ is the proportion of variability in the dataset that is accounted by the model. Variable abbreviations are listed in Table 1.

\begin{tabular}{|c|c|c|}
\hline Landbirds & Shorebirds & Waterfowl \\
\hline \multicolumn{3}{|c|}{ Life History } \\
\hline $\begin{array}{c}-1.09 \text { Average_M } \\
0.85 \text { Range_M } \\
-0.48 \text { Troph_D }\end{array}$ & 0.85 Range_M & $\begin{array}{c}\text { 1.05 Average_M } \\
\text { 0.85 Range_M } \\
\text { 1.38 Troph_D }\end{array}$ \\
\hline \multicolumn{3}{|c|}{ Habitats } \\
\hline $\begin{array}{c}2.99 \times 10^{-5} \text { For_Area } \\
-2.92 \times 10^{-3} \text { For_Np } \\
-1.05 \text { For_Shape } \\
3.29 \times 10^{-4} \text { Wet_Area } \\
-9.49 \times 10^{-3} \text { Wet_Pladj } \\
5.29 \times 10^{-3} \text { Wet_Iji } \\
4.88 \times 10^{-5} \text { Agr_Area }\end{array}$ & $\begin{array}{c}-2.23 \text { For_Shape } \\
0.0003 \text { Wet_Area } \\
0.0065 \text { Wet_Iji } \\
-1.78 \text { Agr_Shape }\end{array}$ & $\begin{array}{c}-2.50 \times 10^{-3} \text { For_Np } \\
-1.31 \text { For_Shape } \\
6.26 \times 10^{-4} \text { Wet_Area } \\
-5.75 \times 10^{-3} \text { Wet_Np }\end{array}$ \\
\hline \multicolumn{3}{|c|}{ Human Disturbance } \\
\hline $\begin{array}{c}-3.88 \times 10^{-4} \text { Infrastr_Area } \\
3.45 \times 10^{-3} \text { Infrastr_Np } \\
4.28 \times 10^{-4} \text { Infrastr_Para } \\
0.065 \text { Infrastr_Pladj }\end{array}$ & $\begin{array}{l}-0.0003 \text { Infrastr_Area } \\
0.0036 \text { Infrastr_Np }\end{array}$ & $\begin{array}{c}-8.54 \times 10^{-4} \text { Infrastr_Area } \\
6.14 \times 10^{-3} \text { Infrastr_Np } \\
8.47 \times 10^{-4} \text { Infrastr_Para } \\
0.12 \text { Infrastr_Pladj } \\
-2.69 \text { Road_Pd }\end{array}$ \\
\hline \multicolumn{3}{|c|}{ Other Variables } \\
\hline $4.61 \times 10^{-3}$ Effort & 0.0076 Effort & $7.54 \times 10^{-3}$ Effort \\
\hline$R^{2}=0.25$ & $R^{2}=0.63$ & $R^{2}=0.43$ \\
\hline
\end{tabular}

\section{Discussion}

Overall, our results show that nearly $27 \%$ of the regional variance in the richness of avian species on PEI could be explained by the factors examined in this study. Higher levels of explained variability (up to 63\%) were obtained when examining avian groups separately, suggesting a potential influence of functional traits on the regional patterns of avian species richness in PEI. The use of $10 \times 10 \mathrm{~km}$ sampling cells helped us to identify some of the factors that are currently shaping avian species richness on PEI. Although species richness values showed strong spatial autocorrelation (Figures 2(a)-(d)), our best predictive models have successfully removed most of this autocorrelation (Figures $2(\mathrm{e})-(\mathrm{h})$ ). This suggests that the observed spatial autocorrelation in species richness was partially due to some of the environmental factors examined here. Having said this, the relatively low and moderate $R^{2}$ values of the models developed in this study indicate that other factors than those examined here are also affecting avian species richness on PEI or that PEI-birds do not have a strong habitat association.

This study examined the role played by $\mathrm{M}$ in determining regional patterns of avian species richness using the interspecific relationship between these two variables and the frequency distribution of both Average_M and Range_M. Our findings indicated that $\mathrm{M}$ is a major determinant of avian species richness on PEI whether all species were pooled together or separated into groups. These 
results are consistent with studies conducted at larger spatial scales which found that $\mathrm{M}$ plays a key role in determining the patterns of other ecological variables [10] [14] [46] [47]. Overall, our models suggested that many avian communities on PEI include a large number of intermediate-sized species, with the variation in $\mathrm{M}$ within communities spanning up to 3 orders of magnitude, reflecting the presence of some large-bodied size species in at least some landscapes.

Several studies that examined $M$ frequency distributions at large spatial scales showed an optimal $\mathrm{M}$ of 30 - $50 \mathrm{~g}$ for bird species resulting mainly from metabolic and/or habitat constraints [48]. In this study, we found that the majority of species within communities were slightly larger $(\sim 50-80 \mathrm{~g})$ than the proposed optimal M. External and physical constraints involving the structure of resources used by bird species on PEI may explain the numerical dominance of species $\sim 50-80 \mathrm{~g}$. A major consequence of the high levels of habitat fragmentation occurring on PEI is that a great proportion of PEI's landscapes are composed of forest and wetland habitat patches of small size. In most agricultural landscapes of PEI, forest habitats have been fragmented into small discrete patches, with approximately $32 \%$ of them being smaller than 0.5 ha [49]. Small and intermediate-sized species may require fewer resources and can partition the environment more effectively than large-bodied ones (also known as "the body size hypothesis"; [50] [51]). Thus, it is possible that intermediate-sized species succeed better on PEI. This also implies that in our region some avian species may occupy habitat patches whose minimum size is proportional to their body size. On the other hand, large-bodied species usually require larger contiguous areas of suitable habitat to meet home-range requirements [52]. Large-bodied terrestrial birds on PEI include some raptors and waterfowl species. Avian predators can be affected by the discontinuous distribution of resources in fragmented landscapes (e.g. [53]). It is likely that most areas of PEI do not include sufficient contiguous areas of suitable habitat to support many populations of large-bodied species. In this study, we did not examine individual species responses to habitat metrics, thus we can only speculate on the specific effects that habitat metrics may have on some species. It is possible that intermediate-sized species may be more affected by the patch size reduction whereas large-bodied ones are more affected by the total amount of suitable habitat in the landscape. Given that there are very few species $>100 \mathrm{~g}$ on PEI, it is possible that the total amount of suitable habitat on PEI's landscapes may indeed be insufficient to support numerous populations of these large-bodied species, although this is not the case for intermediate-sized species.

Another explanation for the paucity of large-bodied avian species is that species at progressively higher trophic levels (i.e. predators) tend to be less abundant with distributions that are more fragmented, particularly in areas where resources are discontinuously distributed [23]. As energy flows through a system, the majority is lost at the lower trophic levels of the energy pyramid, leaving less available energy for species occupying the higher levels of the pyramid. 
Consequently, as population abundance levels decrease and species distributions become more fragmented, the probability of detecting individual species from higher trophic levels in a given landscape during a survey also decreases. Thus, it is possible that some large-bodied species only occurred at very low abundance levels and/or had very fragmented distributions, explaining why they were undetected during the 5-year survey on which this study is based. Since no reliable quantitative records exist with respect to the current abundance of most avian species on PEI, we can only assume that some of the expected, but undetected, large-bodied species were more abundant in the past. This would explain why they were detected in short-term surveys that took place during the late $1800 \mathrm{~s}$ and early 1900s on PEI [27]. The records of these surveys indicated the presence of several landbird and waterfowl large-bodied species that were not detected during the 5-year survey used for this study. Although some of these undetected species are also locally extinct in nearby continental areas (i.e. Nova Scotia and New Brunswick), we speculate that other undetected species are only now occasionally observed on PEI. Thus, one possible explanation for our findings is that the habitat loss and fragmentation that have occurred in the province during the last $\sim 100$ years have resulted in the decline in abundance or local extinction of several large-bodied avian species in some landscapes of PEI. The area-sensitivity of some large-bodied species could reflect, in part, preference of the remaining populations or species for the largest available tracts.

Our findings were also consistent with other studies showing that landscape characteristics affect the patterns of species richness and structure of avian communities [54]. However, it is essential to mention that the effects of most of these variables were relatively weak and varied in importance depending upon the land-cover type. At the spatial scale examined here, our models showed that the shape and the number of forest patches within sampling cells negatively affected avian species richness whether all bird species were pooled together or separated in groups. The combined effects of these two variables suggest a decline in avian species richness as landscapes become dominated by forests that are subdivided into many patches of irregular shape. On PEI, landscapes that would correspond to this description are those resulting from agricultural activities where small forest patches are embedded in a matrix of agricultural fields and hedgerows. Decreased habitat diversity in small forest patches and hedgerows explains, at least partially, the negative relationships between species richness and both the shape and the number of forest patches found in this study. Support for this explanation also comes from studies conducted at large spatial scales that have shown a positive influence of landscape heterogeneity on avifauna diversity in agricultural landscapes [54]. In addition, several species known to occur on PEI (e.g. Red-winged Blackbirds, Agelaius phoenicus, Bobolinks, Dolichonyx oryzivorous) are expected to be sensitive to habitat fragmentation and are more likely to be found in large forest patches. The colonization and use of forest patches by avian species during the breeding season are also often 
associated with patch area (e.g. [55]). If juveniles search for the next year's breeding sites between fledging and migration (e.g. [56]), then both the area and the proximity to the natal area of the bird might affect the chance a bird will utilize a given habitat patch during post-fledging exploration. Thus, if large patches provide higher nest success rates compared to small ones, then they should have a higher return rate of the previous year's nesters and be the most attractive for juveniles and previously unsuccessful nesters. Ultimately, all these factors should affect abundance levels or the probability that an individual species will be detected in a given patch during surveys.

The association between trophic diversity and species richness found in this study was unclear, with only two avian groups showing significant, but weak, relationships. The trophic diversity-species richness relationship was positive for waterfowl, but negative for landbirds. The negative relationship in landbirds may just reflect the rarity or absence of large-bodied predators as previously discussed. Thus, only the results found for waterfowl provide a limited support to the idea that as species richness increases trophic diversity also increases (e.g. [23]).

Another important finding was the role played by wetlands in determining the diversity of the avifauna of PEI. Although our findings were generally in agreement with other studies (e.g. [57]), they clearly indicated that both the fragmentation and isolation of wetlands can have negative effects on the avifauna, especially on landbirds and waterfowl. Our models showed that avian species richness increased with the total area covered by wetlands, implying that any decrease in the total area covered by this habitat type could result in a decrease in avian species richness. Interestingly, species richness increased with the interspersion of wetlands, suggesting that a cluster of wetlands would have more positive effects on species richness than would have isolated wetlands. It is possible that some birds have to complement or supplement resource needs whether they are waterfowl or landbird species [58]. However, our findings also showed that species richness decreased with the number of wetlands. Although at first view this may appear contradictory, this finding may reflect the fact that the number of wetlands is also a measure of the extent of the subdivision of the total area covered by wetlands (i.e. fragmentation; [37]). We can thus infer that any increase in fragmentation of the area covered by wetlands would also result in an increase in the number of small wetlands. Small wetlands may not have adequate heterogeneity in habitat or resources for a large number of species (e.g. [59]) because vegetation diversity tends to be low. In addition, small wetlands are usually shallower than large wetlands, leading to a dominance of cattails, reduction of available open water, and the transformation of wetlands into upland habitats. In larger wetlands, with more habitat types, most avian species have possibly access to their preferred feeding zones in long shores or wide inner areas of deep open water.

There was little evidence that human infrastructures were a major determi- 
nant of the richness of the avifauna of PEI. These findings contradict other studies (e.g. [18]). Having said this, two metrics associated with human infrastructure were important to the avifauna of PEI: the total area covered by human infrastructure and the number of patches they occupied. The negative effect of these two metrics on avian species richness clearly validates the ecosystem-stress hypothesis that states that humans are detrimental to species diversity because they remove habitat and resources of most species [60]. Since this study was conducted at the community level, it is important to point out that different species react differently to the same predictor variable. For instance, many common species benefit from human activities and consequently occur in high densities in altered areas which are otherwise unoccupied by species sensitive to human activities [61]. In PEI, avifaunal assemblages in areas where impermeable human infrastructure tend to be clustered (cities, towns, etc.) are often dominated by invasive species (e.g. European starling; Sturnus vulgaris) and opportunistic species (e.g. American crow; Corvus americanus), while many rare or less common bird species seldom occur in such areas. Since the increase of human infrastructure is often economically unavoidable, these findings highlight the importance of controlling the expansion of human infrastructure on PEI's landscapes or reducing the clustering of habitat patches occupied by impermeable human infrastructure.

The identification of the factors that influence the richness of an avifauna at the regional spatial scale is an essential first step to determine the best strategies to preserve biodiversity. Our study suggests that the loss and fragmentation of wetlands and forests for agricultural purposes has probably contributed to the decline and/or disappearance of various avian species on PEI, especially large-bodied species. Our findings show that the total area covered by wetlands and their interspersion are particularly important for birds, especially those that are area-sensitive and/or large-bodied. Therefore, the conservation and/or restoration of larger ponds in order to preserve extensive open-water zones into the wetlands would be essential to maintain the greatest number of specialist, large-bodied size and/or area-sensitive bird species. Finally, it is critical to mention that even though our models indicate the potential effects of some habitat metrics on avian species richness, data on the presence/absence of species only provide rough approximations of their actual minimal requirements. Long-term demographic data are needed to establish precise estimates of the area required to maintain truly viable avian populations on PEI, especially those of large-body sizes.

\section{Acknowledgements}

This research was supported by research discovery grants from the Natural Sciences and Engineering Research Council of Canada to M. Silva-Opps and S.B. Opps. Personal support to J. Mailhiot was provided through a scholarship from the Harvey Moore Wildlife Foundation. We thank the Prince Edward Island 
Department of Agriculture and Forestry for providing digital information on provincial land-covers.

\section{Conflicts of Interest}

The authors declare no conflicts of interest regarding the publication of this paper.

\section{References}

[1] Currie, D.J. (1991) Energy and Large-Scale Patterns of Animal- and Plant-Species Richness. The American Naturalist, 137, 27-49. https://doi.org/10.1086/285144

[2] Ricklefs, R.E. (2004) A Comprehensive Framework for Global Patterns in Biodiversity. Ecology Letters, 7, 1-15. https://doi.org/10.1046/j.1461-0248.2003.00554.x

[3] Segev, U. (2010) Regional Patterns of Ant-Species Richness in an Arid Region: The Importance of Climate and Biogeography. Journal of Arid Environments, 74, 646-652. https://doi.org/10.1016/j.jaridenv.2009.11.001

[4] Fløjgaard, C., Normand, S., Skov, F. and Svenning, J.C. (2011) Deconstructing the Mammal Species Richness Pattern in Europe-Towards an Understanding of the Relative Importance of Climate, Biogeographic History, Habitat Heterogeneity and Humans. Global Ecology and Biogeography, 20, 218-230. https://doi.org/10.1111/j.1466-8238.2010.00604.x

[5] Rahbek, C. (2005) The Role of Spatial Scale and the Perception of Large-Scale Species-Richness Patterns. Ecology Letters, 8, 224-239. https://doi.org/10.1111/j.1461-0248.2004.00701.x

[6] Lennon, E.T., Beale, C.M., Reid, C.L., Kent, M. and Pakeman, R.J. (2011) Are Richness Patterns of Common and Rare Species Equally Well Explained by Environmental Variables? Ecography, 34, 529-539. https://doi.org/10.1111/j.1600-0587.2010.06669.x

[7] Gaston, K.J. and Blackburn, T.M. (2000) Pattern and Process in Macroecology. Blackwell Scientific Publications, Oxford. https://doi.org/10.1002/9780470999592

[8] Pearson, R.G., Dawson, T.P. and Liu, C. (2004) Modelling Species Distributions in Britain: A Hierarchical Integration of Climate and Land-Cover Data. Ecography, 27, 285-298. https://doi.org/10.1111/j.0906-7590.2004.03740.x

[9] Brown, J.H. and Nicoletto, P.F. (1991) Spatial Scaling of Species Composition-Body Masses of North-American Land Mammals. The American Naturalist, 138, 1478-1512. https://doi.org/10.1086/285297

[10] Silva, M., Brimacombe, M. and Downing, J.A. (2001) Effects of Body Mass, Climate, Geography, and Census Area on Population Density of Terrestrial Mammals. Global Ecology and Biogeography, 10, 469-485. https://doi.org/10.1046/j.1466-822x.2001.00261.x

[11] Brown, J.H., Marquet, P.A. and Taper, M.L. (1993) Evolution of Body Size: Consequences of an Energetic Definition of Fitness. The American Naturalist, 142, 573-584. https://doi.org/10.1086/285558

[12] Blackburn, T.M. and Gaston, K.J. (1994) Animal Body-Size Distributions-Patterns, Mechanisms and Implications. Trends in Ecology \& Evolution, 9, 471-474. https://doi.org/10.1016/0169-5347(94)90311-5

[13] Allen, C.R., Garmestani, A.S., Havlicek, T.D., Marquet, P.A., Peterson, G.D., Restrepo, C., Stow, C.A. and Weeks, B.E. (2006) Patterns in Body Mass Distributions: Sifting 
among Alternative Hypotheses. Ecology Letters, 9, 630-643.

https://doi.org/10.1111/j.1461-0248.2006.00902.x

[14] Arim, M., Bozinovic, F. and Marquet, P.A. (2007) On the Relationship between Trophic Position, Body Mass and Temperature: Reformulating the Energy Limitation Hypothesis. Oikos, 116, 1524-1530. https://doi.org/10.1111/j.0030-1299.2007.15768.x

[15] Blackburn, T.M. and Gaston, K.J. (1996) Spatial Patterns in the Body Size of Bird Species in the New World. Oikos, 77, 436-446. https://doi.org/10.2307/3545933

[16] Cardillo, M. (2002) Body Size and Latitudinal Gradients in Regional Diversity of New World Birds. Global Ecology and Biogeography, 11, 59-65. https://doi.org/10.1046/j.1466-822X.2001.00265.x

[17] Fairbanks, D.H.K. (2004) Regional Land-Use Impacts Affecting Avian Richness in South Africa-Insights from Historical Avian Atlas Data. Agriculture, Ecosystems \& Environment, 101, 269-288. https://doi.org/10.1016/j.agee.2003.09.009

[18] La Sorte, F.A. (2006) Geographical Expansion and Increased Prevalence of Common Species in Avian Assemblages: Implications for Large-Scale Patterns of Species Richness. Journal of Biogeography, 33, 1183-1191. https://doi.org/10.1111/j.1365-2699.2006.01480.x

[19] Zedler, J.B. and Kercher, S. (2005) Wetland Resources: Status, Trends, Ecosystem Services and Restorability. Annual Review of Environment and Resources, 30, 39-74. https://doi.org/10.1146/annurev.energy.30.050504.144248

[20] Mazerolle, M.J. and Villard, M.A. (1999) Patch Characteristics and Landscape Context as Predictors of Species Presence and Abundance: A Review. Ecoscience, 6, 117-124. https://doi.org/10.1080/11956860.1999.11952204

[21] Guldemond, R.A. and van Aarde, R.J. (2010) Forest Patch Size and Isolation as Drivers of Bird Species Richness in Maputaland, Mozambique. Journal of Biogeography, 37, 1884-1893. https://doi.org/10.1111/j.1365-2699.2010.02338.x

[22] Brown, W.P. and Sullivan, P.J. (2005) Avian Community Composition in Isolated Forest Fragments: A Conceptual Revisions. Oikos, 111, 1-8. https://doi.org/10.1111/j.0030-1299.2005.13725.x

[23] Linder, E.T., Villard, M.A., Maurer, B.A. and Schmidt, E.V. (2000) Geographic Range Structure in North American Landbirds: Variation with Migratory Strategy, Trophic Level, and Breeding Habitat. Ecography, 23, 678-686. https://doi.org/10.1111/j.1600-0587.2000.tb00311.x

[24] Stevens, C.E., Gabor, T.S. and Diamond, A.W. (2003) Use of Restored Small Wetlands by Breeding Waterfowl in Prince Edward Island, Canada. Restoration Ecology, 11, 3-12. https://doi.org/10.1046/j.1526-100X.2003.00107.x

[25] Round Table on Resource Land Use and Stewardship (1997) Cultivating Island Solutions. Queens Printer, Charlottetown.

[26] Erskine, A.J. (1992) Atlas of the Breeding Birds of the Maritime Provinces. Nova Scotia Museum and Nimbus Publishing Limited, Halifax.

[27] Sobey, D. (2002) Early Descriptions of the Forests of Prince Edward Island: A Source-Book. Part 1: The French Period 1534-1758. University of Ulster, Jordanstown.

[28] Sibley, C.G. and Monroe, B.L. (1990) Distribution and Taxonomy of Birds of the World. Yale University Press, London.

[29] Harvey, P.H. and Pagel, M.D. (1991) The Comparative Method in Evolutionary Biology. Oxford University Press, New York. 
[30] Abouheif, E. (1999) A Method for Testing the Assumption of Phylogenetic Independence in Comparative Data. Evolutionary Ecology Research, 1, 895-909.

[31] Westoby, M., Leishman, M.R. and Lord, J.M. (1995) On Misinterpreting the "Phylogenetic Correction”. Journal of Ecology, 83, 531-534. https://doi.org/10.2307/2261605

[32] Westoby, M., Leishman, M.R. and Lord, J.M. (1995) Further Remarks on "Phylogenetic Correction”. Journal of Ecology, 83, 727-729. https://doi.org/10.2307/2261640

[33] Westoby, M., Leishman, M.R. and Lord, J.M. (1995) Issues of Interpretation after Relating Comparative Datasets to Phylogeny. Journal of Ecology, 83, 892-893. https://doi.org/10.2307/2261605

[34] Dunning, J.B. (1993) CRC Handbook of Avian Body Masses. CRC Press, Boca Raton.

[35] Blackburn, T.M. and Hawkins, B.A. (2004) Bergmann's Rule and the Mammal Fauna of Northern North America. Ecography, 27, 715-724. https://doi.org/10.1111/j.0906-7590.2004.03999.x

[36] Shannon, C.E. and Weiner, W. (1949) The Mathematical Theory of Communications. Illinois University Press, Urbana.

[37] McGarigal, K. and Marks, B.J. (1995) FRAGSTATS: Spatial Pattern Analysis Program for Quantifying Landscape Structure. USDA Forest Service General Technical Report, PNW-GTR 351, 131. https://doi.org/10.2737/PNW-GTR-351

[38] McGarigal, K. and McComb, W.C. (1995) Relationships between Landscape Structure and Breeding Birds in the Oregon Coast Range. Ecological Monographs, 65, 235-260. https://doi.org/10.2307/2937059

[39] Fahrig, L. (1997) Relative Effects of Habitat Loss and Fragmentation on Population Extinction. The Journal of Wildlife Management, 61, 603-610. https://doi.org/10.2307/3802168

[40] Villard, M.A., Trzcinski, M.K. and Merriam, G. (1999) Fragmentation Effects on Forest Birds: Relative Influence of Woodland Cover and Configuration on Landscape Occupancy. Conservation Biology, 13, 774-783. https://doi.org/10.1046/j.1523-1739.1999.98059.x

[41] Legendre, P. (1993) Spatial Autocorrelation: Trouble or New Paradigm? Ecology, 74, 1659-1673. https://doi.org/10.2307/1939924

[42] van Rensburg, B.J., Chown, S.L. and Gaston, K.J. (2002) Species Richness, Environmental Correlates, and Spatial Scale: A Test Using South African Birds. The American Naturalist, 159, 566-577. https://doi.org/10.1086/339464

[43] Diniz-Filho, J.A.F., Bini, L.M. and Hawkins, B.A. (2003) Spatial Autocorrelation and Red Herrings in Geographical Ecology. Global Ecology and Biogeography, 12, 53-64. https://doi.org/10.1046/j.1466-822X.2003.00322.x

[44] ver Hoef, J.M. and Boveng, P.L. (2007) Quasi-Poisson vs. Negative Binomial Regression: How Should We Model Overdispersed Count Data? Ecology, 88, 2766-2772. https://doi.org/10.1890/07-0043.1

[45] McCullagh, P. and Nelder, J.A. (1989) Generalized Linear Models. 2nd Edition, Chapman and Hall, London. https://doi.org/10.1007/978-1-4899-3242-6

[46] Kelt, D.A. and van Vuren, D.H. (2001) The Ecology and Macroecology of Mammalian Home Range Area. The American Naturalist, 157, 637-645. https://doi.org/10.1086/320621

[47] Silva, M., Brown, J.H. and Downing, J.A. (1997) Differences in Population Density 
and Energy Use between Birds and Mammals: A Macroecological Perspective. Journal of Animal Ecology, 66, 327-340. https://doi.org/10.2307/5979

[48] Maurer, B.A. (1998) The Evolution of Body Size in Birds. I. Evidence for Non-Random Distributions. Evolutionary Ecology, 12, 925-934. https://doi.org/10.1023/A:1006512121434

[49] Hutchison, G.E. (1959) Homage to Santa Rosalia, or Why Are There So Many Kinds of Animals? The American Naturalist, 93, 145-159. https://doi.org/10.1086/282070

[50] State of the Forest (2003) Planning the Future. Department of Agriculture and Forestry, Prince Edward Island.

[51] Stanley, S.M. (1973) An Explanation for Cope's Rule. Evolution, 27, 1-26. https://doi.org/10.1111/j.1558-5646.1973.tb05912.x

[52] Haskell, J.P., Ritchie, M.E. and Olff, H. (2002) Fractal Geometry Predicts Varying Body Size Scaling Relationships for Mammal and Bird Home Ranges. Nature, 418, 527-530. https://doi.org/10.1038/nature00840

[53] Gehring, T.M. and Swihart, R.K. (2003) Body Size, Niche Breadth, and Ecologically Scaled Responses to Habitat Fragmentation: Mammalian Predators in an Agricultural Landscape. Biological Conservation, 109, 283-295. https://doi.org/10.1016/S0006-3207(02)00156-8

[54] Acevedo, M.A. and Restrepo, C. (2008) Land-Cover and Land-Use Change and Its Contributions to the Large-Scale Organization of Puerto Rico's Bird Assemblages. Diversity and Distributions, 14, 114-122. https://doi.org/10.1111/j.1472-4642.2007.00435.x

[55] Boulinier, T., Nichols, J.D., Hines, J.E., Sauer, C.H., Flather, C.H. and Pollock, K.H. (2001) Forest Fragmentation and Bird Community Dynamics: Inference at Regional Scales. Ecology, 82, 1159-1169. https://doi.org/10.1890/0012-9658(2001)082[1159:FFABCD]2.0.CO;2

[56] Helzer, C.J. and Jelinski, D.E. (1999) The Relative Importance of Patch Area and Perimeter-Area Ratio to Grassland Breeding Birds. Ecological Applications, 9, 1448-1458. https://doi.org/10.1890/1051-0761(1999)009[1448:TRIOPA]2.0.CO;2

[57] Rey-Benayas, J.M., Colomer, M.G.S. and Levassor, C. (1999) Effects of Area, Environmental Status and Environmental Variation on Species Richness per Unit Area in Mediterranean Wetlands. Journal of Vegetation Science, 10, 275-280. https://doi.org/10.2307/3237149

[58] Haig, S.M., Mehlman, D.W. and Oring, L.W. (1998) Avian Movements and Wetland Connectivity in Landscape Conservation. Conservation Biology, 12, 749-758. https://doi.org/10.1046/j.1523-1739.1998.97102.x

[59] Hoyer, M.V. and Canfield, D.E. (1994) Bird Abundance and Species Richness on Florida Lakes: Influence of Trophic Status, Lake Morphology, and Aquatic Macrophytes. Hydrobiologia, 279/280, 107-119. https://doi.org/10.1007/BF00027846

[60] Lepczyk, C.A., Flather, C.H., Radeloff, V.C., Pidgeon, A.M., Hammer, R.B. and Liu, A.J. (2008) Human Impacts on Regional Avian Diversity and Abundance. Conservation Biology, 22, 405-406. https://doi.org/10.1111/j.1523-1739.2008.00881.x

[61] Harcourt, A.H. and Parks, S.A. (2003) Threatened Primates Experience High Human Densities: Adding an Index of Threat to the IUCN Red List Criteria. Biological Conservation, 109, 137-149. https://doi.org/10.1016/S0006-3207(02)00146-5 


\section{Appendix}

Table A1. Comparison of candidate generalized linear models (GLM) used to relate species richness to explanatory variables for all avian species pooled together and for separated avian groups. AIC values were not available (N/A) for GLMs that used the Quasi-Poisson procedure. No genuine $R^{2}$ values are available in generalized linear models, so we approximated $R^{2}$ values by dividing the deviance statistic by the percentage deviation explained by the model.

\begin{tabular}{|c|c|c|c|c|}
\hline $\begin{array}{l}\text { Regression } \\
\text { Procedure }\end{array}$ & $\begin{array}{l}\text { Akaike's } \\
\text { Information } \\
\text { Criterion (AIC) }\end{array}$ & $\begin{array}{l}R^{2} \\
(\%)\end{array}$ & $\begin{array}{l}\text { Number of } \\
\text { explanatory variables } \\
\text { in the Model }\end{array}$ & $\begin{array}{l}\text { Presence of spatial } \\
\text { autocorrelation in } \\
\text { residuals }\end{array}$ \\
\hline \multicolumn{5}{|l|}{ All Birds } \\
\hline Quasi-Poisson & N/A & 25.9 & 15 & Yes \\
\hline Negative Binomial & 618.76 & 26.0 & 17 & Yes \\
\hline Poisson & 661.35 & 26.9 & 13 & Yes \\
\hline \multicolumn{5}{|l|}{ Landbirds } \\
\hline Quasi-Poisson & N/A & 24.1 & 17 & Yes \\
\hline Negative Binomial & 588.71 & 24.0 & 12 & Yes \\
\hline Poisson & 610.46 & 25.0 & 15 & No \\
\hline \multicolumn{5}{|l|}{ Shorebirds } \\
\hline Quasi-Poisson & N/A & 57.2 & 11 & Yes \\
\hline Negative Binomial & 264.82 & 57.3 & 11 & Yes \\
\hline Poisson & 262.27 & 63.0 & 8 & No \\
\hline $\begin{array}{l}\text { Regression } \\
\text { Procedure }\end{array}$ & $\begin{array}{l}\text { Akaike's } \\
\text { Information } \\
\text { Criterion (AIC) }\end{array}$ & $\begin{array}{l}R^{2} \\
(\%)\end{array}$ & $\begin{array}{l}\text { Number of explanatory } \\
\text { variables in the Model }\end{array}$ & $\begin{array}{l}\text { Presence of spatial } \\
\text { autocorrelation in } \\
\text { residuals }\end{array}$ \\
\hline \multicolumn{5}{|l|}{ Waterfowl } \\
\hline Quasi-Poisson & N/A & 42.5 & 14 & Yes \\
\hline Negative Binomial & 346.13 & 42.5 & 14 & Yes \\
\hline Poisson & 342.78 & 43.0 & 13 & No \\
\hline
\end{tabular}

